\title{
EFFECTS OF SUBSTRATE AND WATER AVAILABILITY ON THE INITIAL GROWTH OF Alibertia edulis RICH.
}

\author{
Tatiane Sanches Jeromini*1, Leandro Henrique de Sousa Mota², Silvana de Paula Quintão Scalon ${ }^{3}$, Daiane \\ Mugnol Dresch ${ }^{3}$, Lourenço Quintão Scalon ${ }^{3}$ \\ ${ }^{1}$ Universidade Estadual Paulista, Faculdade de Ciências Agrárias e Veterinárias, Jaboticabal, São Paulo, Brasil. \\ E- mail: tatiane_jeromini@hotmail.com \\ ${ }^{2}$ Syngenta Seeds Ltda, Cascavel, Paraná, Brasil. E-mail: leandro.mota@syngenta.com \\ 32Universidade Federal da Grande Dourados, Faculdade de Ciências Agrárias, Brasil. E-mail: SilvanaScalon@ufgd.edu.br, \\ daiamugnol@hotmail.com, lourenso.scalon@hotmail.com \\ *Autor correspondente
}

Received for publication: 21/12/2017 - Accepted for publication: 01/06/2018

\begin{abstract}
Alibertia edulis Rich. is a native species of the Brazilian Cerrado and can be used for reforestation of degraded areas. In addition, it produces edible fruits. The objective of this study was to evaluate the effect of substrates and water levels on the emergence, initial growth, and quality of seedling of A. edulis. The substrates tested were: latosol $(\mathrm{L})$, latosol + sand $(\mathrm{L}+\mathrm{S}=1: 1)$, latosol + sand + chicken manure $(\mathrm{L}+\mathrm{S} 1+\mathrm{CM}=1: 1: 0,5)$, latosol + sand + chicken manure $(\mathrm{L}+\mathrm{S} 2+\mathrm{CM}=1: 2: 0,5)$, and latosol + commercial substrate $(\mathrm{L}+\mathrm{C}=1: 1)$; and the water retention capacities (WRC) tested were: 25, 50, 75, and $100 \%$. The experiment was carried through in a completely randomized design and subdivided into a plot scheme, in which the plots represented water availability and the subplots represented the substrates. Latosol + commercial substrate at $100 \%$ of WRC provided the best conditions for emergence, initial growth and formation of seedlings of A. edulis. Sowing in the substrate Dystroferric Red Latosol isolated at $25 \%$ of WRC should not be used for the formation of seedlings of this species.

Keywords: Emergence, Cerrado fruit, plant propagation, Rubiaceae.
\end{abstract}

\section{Resumo}

Substrato e disponibilidade hídrica no crescimento inicial plântulas de Alibertia edulis Rich. A espécie nativa Alibertia edulis Rich., conhecida popularmente como marmelo, pode ser aproveitada para reflorestamentos visando à recuperação de áreas degradadas, e seus frutos podem ser usados na culinária. Sendo assim, objetivou-se no presente trabalho avaliar o efeito de substratos e níveis de água na emergência, crescimento inicial e qualidade de mudas de A. edulis. Foram avaliados os substratos: latossolo (L), latossolo + areia $(\mathrm{L}+\mathrm{A}=1: 1)$, latossolo + areia + cama-de-frango $(\mathrm{L}+\mathrm{A}+\mathrm{CF}=1: 1: 0,5)$, latossolo + areia + cama-de-frango $(\mathrm{L}+\mathrm{A}+\mathrm{CF}=1: 2: 0,5)$ e latossolo + substrato comercial $(\mathrm{L}+\mathrm{C}=1: 1)$; e as disponibilidades hídricas de 25, 50,75 e $100 \%$ da capacidade de retenção de água (CRA). O experimento foi realizado em delineamento inteiramente casualizado, em esquema de parcela subdividida, sendo as parcelas representantes das disponibilidades hídricas e as subparcelas, os substratos. O substrato composto por latossolo + substrato comercial a $100 \%$ de CRA proporciou as melhores condições para emergência, crescimento inicial e formação de mudas de A. edulis. A semeadura no substrato Latossolo Vermelho Distroférrico isolado a $25 \%$ da CRA não deve ser utilizada para a formação de mudas de $A$. edulis.

Palavras-chave: Emergência, frutífera do Cerrado, propagação de plantas, Rubiaceae.

\section{INTRODUCTION}

The Brazilian Cerrado is characterized by a varied physiognomic composition, ranging from open fields to closed forests. This region consists of approximately two million square kilometers of the Brazilian territory, mostly in the central part of the country (RIBEIRO; WALTER, 2008). This biome is characterized by high biological diversity, with thousands of endemic plant species. Among them, many species are agriculturally and medicinally important, having economic potential. Therefore, research to improve the knowledge of these species and the ability to take advantage of their potential is necessary (SCALON et al., 2014).

Alibertia edulis (L.C. Rich.) A.C. Rich (Rubiaceae), known as "marmelo", is a notable species of this biodiversity for its use in reforestation of degraded areas. This species can be consumed both in its natural form and as processed candies, jellies, and juices. It also has medicinal action, specifically as an anti-inflammatory (AQUINO et al., 2017). However, there are few studies on the propagation and production of seedlings of this species, mainly with the aim at taking this knowledge to nurseries of native plants (NUNES et al., 2014). 
In the production of seedlings, the substrate and amount of applied water directly interfere with the emergence of the seedling and its final quality. It may also interfere with the survival of the plant. Differences in substrate effects occur mainly due to differences in physical, chemical, and biological properties, which can affect the germination and establishment of seedlings (SILVA et al., 2011).

The choosing of a substrate should be based on cost and availability, among other factors. As such, several mixtures are available for the production of seedlings from forest species. For example, latosol is recommended for the production of Hancornia speciosa (GORDIN et al., 2016), while soil with either added sand or commercial substrate is preferred for Campomanesia adamandium (DRESCH et al., 2016). Bioplant ${ }^{\circledR}$ is indicated for Peltophorum dubium (DUTRA et al., 2012), and latosol with added sand and chicken manure is ideal for Eugenia pyriformis (SCALON et al., 2014; SCALON; JEROMINE, 2013).

In addition, understanding the relationship between plants and water, specifically absorption, transport, and water loss, helps to create strategies for the survival of certain species in regions with lack or excess of water. Furthermore, this understanding would aid in reducing costs during the nursery production process, mainly regarding to labor, water, and energy (DRESCH et al., 2016). An incorrect amount of water available for the plant can cause morphophysiological changes depending on the species, especially in the early stages. In the absence of water, plants may suffer loss of turgidity, reduced growth, foliar reduction, stomatal closure, and eventual foliar abscission (SCALON; JEROMINE, 2013; GORDIN et al., 2016; DRESCH et al., 2016). In contrast, excessive water can decrease the amount of available oxygen and slow respiration, cause cell death and decrease the growth and nutrient absorption by the root system (OLIVEIRA; JOLY, 2010).

Assuming that the behavior of species in the initial stages is different according to substrates and water availability, the objective of this study was to evaluate the effect of different substrata and degrees of water availability on emergence, initial growth and quality of the seedlings of Alibertia edulis.

\section{MATERIAL AND METHODS}

A. edulis fruits were harvested after ripening, as indicated by a peel blackening. They were collected from 20 cultivated matrices at the Santa Madalena Farm, located in the municipality of Dourados, state of Mato Grosso do Sul, Brazil ( $23^{\circ} 8^{\prime} 17^{\prime} \mathrm{S}, 55^{\circ} 8^{\prime} 15^{\prime} \mathrm{W}$; elevation of $\left.436 \mathrm{~m}\right)$. The climate in this area is classified as Cwa (Köppen) (FIETZ; FISCH, 2006).

After the fruits were collected, they were transported to the Laboratory of Plant Nutrition Metabolism at the Federal University of Grande Dourados (Dourados, state of Mato Grosso do Sul, Brazil), where they were processed to remove the pulp through a metallic sieve and running water. Whole seeds that showed no signs of damage or deterioration were selected. The water content of the seeds was determined by using two samples, each one with a mass of $3 \mathrm{~g}$ (NUNES et al., 2014). These seeds were subjected to the oven method at $105 \pm 2{ }^{\circ} \mathrm{C}$ for $24 \mathrm{~h}$ (BRASIL, 2013). Humidity of $19 \%$ was found.

The seeds were planted at a depth of $1 \mathrm{~cm}$ in $50 \times 190 \mathrm{~mm}\left(120 \mathrm{~cm}^{3}\right)$ tubes. The tested substrates (v:v) consisted of comprised latosol (L), latosol + sand $(\mathrm{L}+\mathrm{S}=1: 1)$, latosol + sand + chicken manure $(\mathrm{L}+\mathrm{S} 1+\mathrm{CM}=1: 1: 0,5)$, latosol + sand + chicken manure $(\mathrm{L}+\mathrm{S} 2+\mathrm{CM}=1: 2: 0,5)$, and latosol + commercial substrate $(\mathrm{L}+\mathrm{C}=1: 1)$. The aforementioned ratios were measured by volume. The water retention capacity (WRC) was determined by adopting the water content retained by each substrate after the excess flow, i.e., a volume of each dry substrate was placed in a paper filter and then a predetermined amount of water was added, waiting until all water excess was drained. This volume was determined to enable calculations by the WRC of $25 \%, 50 \%$ and $75 \%$ according to the calculation presented in Brazil (2013). Manual irrigation was performed daily with scales to help controlling the desired WRC. Plant growth measurements were performed 175 days after planting.

The soil was collected in the municipality of Dourados, where A. edulis naturally occurs. The soil in this region is classified as Clayey Dystroferric Red Latosol (SANTOS et al., 2013). The sand used in this study had thick grains ( 0.5 to $1.0 \mathrm{~mm}$ of diameter), and the commercial substrate (Bioplant $\left.{ }^{\circledR}\right)$ consisted of pine bark, coconut fiber, vermiculite, and macro and micronutrients (their identities were not revealed by the manufacturer). The soil has $\mathrm{pH}$ between 5.2 and 6.5 and electrical conductivity between 0.6 and $1.4 \mu \mathrm{S} \mathrm{cm}{ }^{-1}$. Lastly, the chicken manure used in this study was partially decomposed. It was left fermenting for 60 days, which corresponds to the humification phase of organic matter. The chemical analysis of the substrates is presented in Table 1. 
Table 1. Chemical analysis of the substrates used to produce seedlings of Alibertia edulis.

Tabela 1. Análise química dos substratos utilizados para produção de plântulas de Alibertia edulis.

\begin{tabular}{|c|c|c|c|c|c|c|c|c|c|c|}
\hline Substrate $^{1}$ & $\begin{array}{l}\mathbf{O M}^{1} \\
\left(\mathrm{~g} . \mathrm{dm}^{-3}\right)\end{array}$ & $\begin{array}{l}\mathbf{p H} \\
\left(\mathrm{CaCl}_{2}\right)\end{array}$ & $\begin{array}{l}\mathbf{P}^{\mathbf{2}} \\
\left(\mathrm{mg} \cdot \mathrm{dm}^{-3}\right)\end{array}$ & $\begin{array}{l}\mathbf{K}^{2} \\
\ldots \ldots\end{array}$ & $\begin{array}{c}\mathbf{C a} \\
.\left(\mathrm{mmol}_{\mathrm{c}}\right.\end{array}$ & $\begin{array}{c}\mathbf{M g} \\
\left.\mathrm{dm}^{-3}\right) .\end{array}$ & $\mathbf{H}+\mathbf{A l}$ & BS & AEC & $\begin{array}{l}\mathbf{V} \\
(\%)\end{array}$ \\
\hline $\mathrm{L}$ & 13,2 & 3,8 & 1,0 & 2,4 & 14,0 & 5,0 & 105,0 & 21,4 & 126,4 & 16 \\
\hline $\mathrm{L}+\mathrm{S}$ & 3,9 & 4,4 & 0,0 & 1,5 & 17,0 & 7,0 & 36,0 & 25,5 & 61,5 & 41 \\
\hline $\mathrm{L}+\mathrm{S} 1+\mathrm{CM}$ & 3,0 & 6,1 & 67,0 & 56,0 & 28,0 & 27,0 & 19,0 & 111,0 & 130,0 & 85 \\
\hline $\mathrm{L}+\mathrm{S} 2+\mathrm{CM}$ & 3,9 & 5,6 & 131,0 & 25,5 & 21,0 & 15,0 & 18,0 & 61,5 & 79,5 & 77 \\
\hline $\mathrm{L}+\mathrm{C}$ & 84,0 & 4,6 & 51,0 & 16,0 & 59,0 & 41,0 & 80,0 & 116,0 & 196,0 & 59 \\
\hline
\end{tabular}

${ }^{1}$ Walkley \& Black Method; ${ }^{2}$ Mehlich Extractor. $(\mathrm{L})=$ latosol; $(\mathrm{L}+\mathrm{S})=$ latosol + sand in a ratio of $1: 1 ;(\mathrm{L}+\mathrm{S} 1=\mathrm{CM})=$ latosol + sand + chicken manure in a ratio of 1:1:0.5; $(\mathrm{L}+\mathrm{S} 2+\mathrm{CM})=$ latosol + sand + chicken manure in the ratio of $1: 2: 0.5 ;(\mathrm{L}+\mathrm{C})=$ latosol + commercial substrate in a ratio of $1: 1$

The tubes with seeds were placed in polypropylene trays and kept in a greenhouse with $50 \%$ of shading at a temperature of $28 \pm 3{ }^{\circ} \mathrm{C}$ and relative humidity of $50 \% \pm 3 \%$. The experimental design was completely randomized and structured in a subdivided plot scheme. Plots were organized by water availability, while subplots were organized by substrates. In order to evaluate the effect of the treatments on the emergence and growth of seedlings, the following characteristics were analyzed:

a) Emergence of the seedling (E): evaluated by counting emerged normal seedlings on the $35^{\text {th }}$ day after planting. Seedlings were counted as emerged if part of the hypocotyl was visible outside the substrate and seemed to be complete and healthy, or with minimal damage that would not affect the development. These seedlings would have the potential to yield plants under favorable field conditions (BRASIL, 2013). The results were presented in percentage.

b) Emergence speed index (ESI): calculated together with the emergence. This factor was determined by counting the number of emerged normal seedlings that had emerged on a daily basis and applying the methodology and formula proposed by Maguire (1962).

c) Length of the shoot and root parts (LS and LR): evaluated by measuring the distance between the base of the stem and the insertion point of the last leaf and the root cap, respectively, through a ruler delineated in millimeters. The values were expressed in centimeters.

d) Collar diameter $(\mathrm{CD})$ : determined with the aid of a digital caliper applied close to the substrate. The results were expressed in millimeters per plant.

e) Leaf area (LA): measured using all expanded leaves with the aid of a leaf area integrator LCI3000. The results were expressed in square centimeters per plant.

f) Chlorophyll index (CI): measured using a Minolta chlorophyll meter, model SPAD-502. The mean of the three measurements of the second expanded leaf of each seedling was used as the final value, expressed in SPAD index.

g) Shoot and root dry mass (SDM and RDM): the seedlings were sectioned by separating their shoot parts from their roots. Both parts were packed in Kraft paper bags and placed to dry in an oven with forced air circulation at $65{ }^{\circ} \mathrm{C}$. Once their weight was constant, they were weighed on a scale with precision of down to $0.001 \mathrm{~g}$. The results were expressed in grams per plant.

h) Dickson quality index (DQI): determined as a function of the shoot part length (SPL), shoot diameter (SD), shoot dry weight (SDW), and root dry weight (RDW), formula proposed by Dickson et al. (1960).

\section{RESULTS}

Table 2 shows the results of the variance analysis for the evaluated characteristics. In all cases, there was significant interaction between treatments, except for root dry mass and Dickson quality index.

Table 2. Variance analysis for emergence of the seedling (E), emergence speed index (ESI), length of the shoot part (LS), length of the root part (LR), leaf area (LA), shoot dry mass (SDM), root dry mass (RDM), collar diameter (CD), Dickson quality index (DQI), and chlorophyll index (CI) of seedlings of Alibertia edulis according to different substrates (S) and water retention capacities (WRC).

Tabela 2. Análise de variância de emergência (E), índice de velocidade de emergência (ESI), comprimento de parte aérea (LS), comprimento da raiz (LR), área foliar (LA), massa seca de parte aérea (SDM), massa seca da raiz (RDM), diâmetro do colo (CD), índice de qualidade de Dickson (DQI), e índice de clorofila (CI) de plântulas de Alibertia edulis em função de diferentes substratos (S) e capacidades de retenção de água (WRC). 


\begin{tabular}{lcccrr}
\hline Evaluated & \multicolumn{5}{c}{ Variation factor } \\
\cline { 2 - 5 } parameters & Substrate & WRC & S x WRC & Mean & C.V. $(\%)$ \\
\hline E $(\%)$ & $18,47^{* * *}$ & $102,62^{* *}$ & $8,49^{* *}$ & 15,38 & 35,78 \\
ESI & $19,69^{* *}$ & $78,43^{* *}$ & $9,05^{* *}$ & 0,05 & 38,52 \\
LS $(\mathrm{cm})$ & $64,85^{* *}$ & $85,22^{* *}$ & $7,86^{* *}$ & 2,94 & 9,89 \\
LR $(\mathrm{cm})$ & $8,75^{* *}$ & $32,40^{* *}$ & $12,07^{* *}$ & 6,65 & 12,89 \\
LA $\left(\mathrm{cm}^{2}\right)$ & $69,10^{* * *}$ & $23,04^{* *}$ & $9,45^{* *}$ & 9,64 & 7,57 \\
SDM $(\mathrm{g})$ & $72,65^{* * *}$ & $51,74^{* *}$ & $3,18^{* *}$ & 0,09 & 12,20 \\
RM $(\mathrm{g})$ & $18,63^{* *}$ & $36,11^{* *}$ & $1,64^{\text {ns }}$ & 0,07 & 17,02 \\
CD $(\mathrm{mm})$ & $66,21^{* * *}$ & $79,25^{* *}$ & $3,02^{* *}$ & 1,17 & 7,47 \\
DQI & $9,37^{* * *}$ & $16,96^{* *}$ & $0,52^{\text {ns }}$ & 0,04 & 22,60 \\
CI (SPAD) & $38,02^{* *}$ & $6,04^{* *}$ & $3,66^{* *}$ & 26,23 & 2,66 \\
\hline
\end{tabular}

$*, * * \mathrm{e}^{\mathrm{ns}}=$ significant value for $\mathrm{p} \leq 0,05, \mathrm{p} \leq 0,01$ and not significant by the test $\mathrm{F} ; \mathrm{CV}=$ coefficient of variation.

The cultivation conditions of that provided the highest percentage of emerged seedlings were latosol + commercial substrate at $100 \%$ of WRC, latosol + sand at $75 \%$ of WRC, and latosol + sand at $100 \%$ of WRC, with values of $48 \%, 50 \%$, and $36 \%$, respectively (Figure 1).

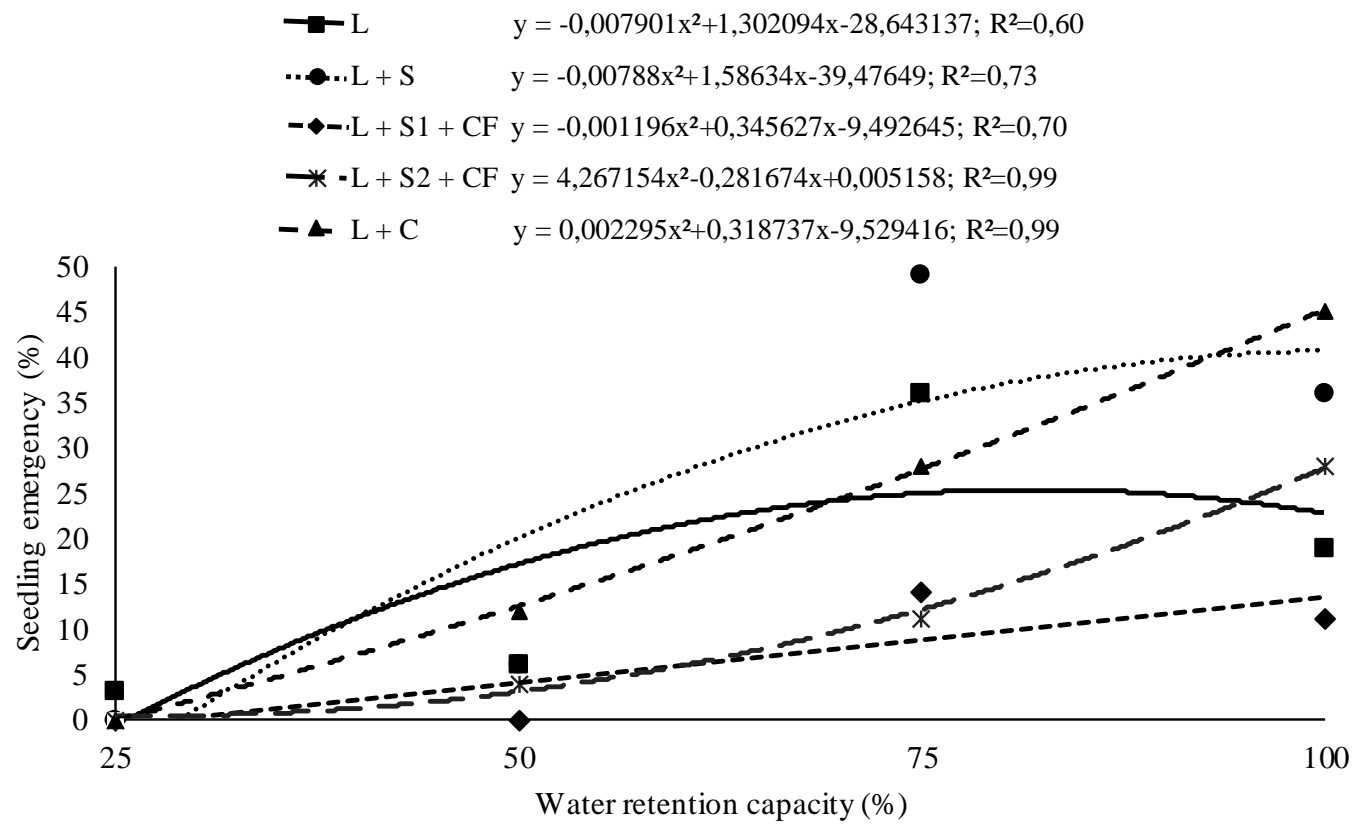

Figure 1. Emergence of the seedling of Alibertia edulis due to different substrates and water retention capacities.

Figura 1. Emergência de plântulas de Alibertia edulis em função de diferentes substratos e capacidades de retenção de água.

By comparing the effect of substrates and water availability on the rates of emergence, it is observed that, for the emergence percentage, substrate latosol + sand, and latosol + commercial substrate at $75 \%$ and $100 \%$ of WRC showed the highest emergence rates and percentages (Figure 2). 


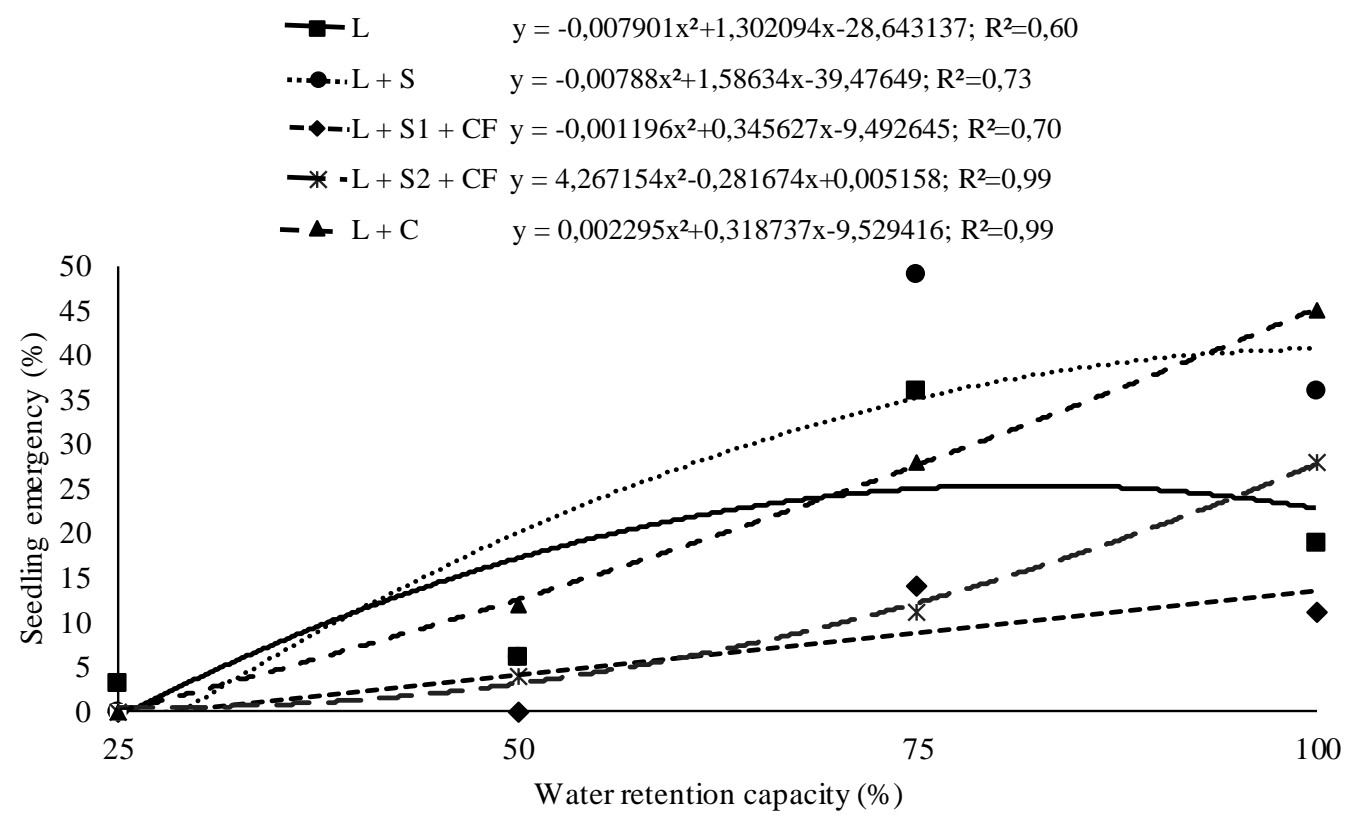

Figure 2. Emergence speed index of Alibertia edulis according to different substrates and water retention capacities.

Figura 2. Índice de velocidade de emergência de plântulas de Alibertia edulis em função de diferentes substratos e capacidades de retenção de água.

Due to the low germination potential of A. edulis seeds at lower WRC values, the growth of seedling was not monitored for this treatment. Overall, latosol + commercial substrate at $100 \%$ of WRC, followed by substrate latosol + sand at $100 \%$ of WRC, had the highest average of values when considering all the growth parameters that were evaluated (Table 3 ). Higher averages in the substrates latosol + commercial substrate, followed by latosol + sand at $100 \%$ of WRC, were observed.

Lower values for leaf area and dry mass accumulation were observed in cases of lower water availability, mainly when chicken manure was not added to the substrate. The highest values for seedling root growth were observed for the latosol under $50 \%$ of WRC.

Table 3. Length of shoot part, collar diameter, leaf area, length of root part, shoot dry mass, and chlorophyll index for seedlings of Alibertia edulis according to different substrates and water retention capacities.

Tabela 3. Comprimento de parte aérea, diâmetro do colo, área foliar, comprimento de raiz, massa seca de parte aérea e teor de clorofila de plântulas de Alibertia edulis em função de diferentes substratos e capacidades de retenção de água.

\begin{tabular}{lllcc}
\hline \multirow{2}{*}{ Evaluated parameters } & Substrate & \multicolumn{3}{c}{ Water retention capacity (\%) } \\
\cline { 2 - 4 } & & $\mathbf{5 0}$ & $\mathbf{7 5}$ & $\mathbf{1 0 0}$ \\
\hline \multirow{3}{*}{ Length of aerial part $(\mathrm{cm})$} & $\mathrm{L}$ & $1,6 \mathrm{cA}$ & $1,7 \mathrm{dA}$ & $2,1 \mathrm{cA}$ \\
& $\mathrm{L}+\mathrm{S}$ & $2,2 \mathrm{bcC}$ & $3,8 \mathrm{abB}$ & $4,6 \mathrm{aA}$ \\
& $\mathrm{L}+\mathrm{S} 1+\mathrm{CM}$ & $3,0 \mathrm{aA}$ & $3,2 \mathrm{bcA}$ & $3,4 \mathrm{bA}$ \\
& $\mathrm{L}+\mathrm{S} 2+\mathrm{CM}$ & $1,5 \mathrm{cB}$ & $2,8 \mathrm{cA}$ & $3,3 \mathrm{bA}$ \\
& $\mathrm{L}+\mathrm{C}$ & $2,7 \mathrm{abC}$ & $3,9 \mathrm{aB}$ & $4,6 \mathrm{aA}$ \\
\hline \multirow{5}{*}{ Collar diameter $(\mathrm{mm})$} & $\mathrm{L}$ & $0,8 \mathrm{cB}$ & $0,8 \mathrm{cB}$ & $1,0 \mathrm{cA}$ \\
& $\mathrm{L}+\mathrm{S}$ & $1,3 \mathrm{aB}$ & $1,4 \mathrm{aB}$ & $1,6 \mathrm{aA}$ \\
& $\mathrm{L}+\mathrm{S} 1+\mathrm{CM}$ & $0,9 \mathrm{bcB}$ & $1,0 \mathrm{bB}$ & $1,3 \mathrm{bA}$ \\
& $\mathrm{L}+\mathrm{S} 2+\mathrm{CM}$ & $1,0 \mathrm{bB}$ & $1,1 \mathrm{bB}$ & $1,3 \mathrm{bA}$ \\
& $\mathrm{L}+\mathrm{C}$ & $1,0 \mathrm{bC}$ & $1,4 \mathrm{aB}$ & $1,6 \mathrm{aA}$ \\
\hline \multirow{5}{*}{ Leaf area $\left(\mathrm{cm}^{2}\right)$} & $\mathrm{L}$ & $5,6 \mathrm{cB}$ & $5,6 \mathrm{bB}$ & $7,7 \mathrm{cA}$ \\
& $\mathrm{L}+\mathrm{S}$ & $10,3 \mathrm{aB}$ & $10,6 \mathrm{aB}$ & $12,3 \mathrm{aA}$ \\
& $\mathrm{L}+\mathrm{S} 1+\mathrm{CM}$ & $10,6 \mathrm{aA}$ & $11,0 \mathrm{aA}$ & $10,0 \mathrm{bA}$ \\
& $\mathrm{L}+\mathrm{S} 2+\mathrm{CM}$ & $9,0 \mathrm{abA}$ & $9,3 \mathrm{aA}$ & $9,0 \mathrm{bcA}$ \\
& $\mathrm{L}+\mathrm{C}$ & $8,3 \mathrm{bC}$ & $11,0 \mathrm{aB}$ & $14,0 \mathrm{aA}$ \\
\hline
\end{tabular}

FLORESTA, Curitiba, PR, v. 49, n. 1, p. 089-098, jan/mar. 2019

Jeromini. T. S. et.al. 


\begin{tabular}{llllr} 
& $\mathrm{L}$ & $8,1 \mathrm{aA}$ & $6,9 \mathrm{abAB}$ & $6,2 \mathrm{cB}$ \\
& $\mathrm{L}+\mathrm{S}$ & $5,8 \mathrm{bB}$ & $6,3 \mathrm{bB}$ & $9,2 \mathrm{abA}$ \\
Length of root part $(\mathrm{cm})$ & $\mathrm{L}+\mathrm{S} 1+\mathrm{CM}$ & $5,0 \mathrm{bcA}$ & $5,2 \mathrm{bA}$ & $6,2 \mathrm{cA}$ \\
& $\mathrm{L}+\mathrm{S} 2+\mathrm{CM}$ & $5,2 \mathrm{bcB}$ & $4,9 \mathrm{bB}$ & $8,2 \mathrm{bcA}$ \\
& $\mathrm{L}+\mathrm{C}$ & $3,6 \mathrm{cB}$ & $8,6 \mathrm{aA}$ & $10,3 \mathrm{aA}$ \\
\hline \multirow{3}{*}{ Shoot dry mass $(\mathrm{g})$} & $\mathrm{L}$ & $0,040 \mathrm{cB}$ & $0,050 \mathrm{cAB}$ & $0,070 \mathrm{cA}$ \\
& $\mathrm{L}+\mathrm{S}$ & $0,090 \mathrm{abC}$ & $0,123 \mathrm{aB}$ & $0,168 \mathrm{aA}$ \\
& $\mathrm{L}+\mathrm{S} 1+\mathrm{CM}$ & $0,077 \mathrm{bA}$ & $0,090 \mathrm{bA}$ & $0,097 \mathrm{bcA}$ \\
& $\mathrm{L}+\mathrm{S} 2+\mathrm{CM}$ & $0,067 \mathrm{bcB}$ & $0,080 \mathrm{bAB}$ & $0,100 \mathrm{bA}$ \\
& $\mathrm{L}+\mathrm{C}$ & $0,110 \mathrm{aB}$ & $0,127 \mathrm{aB}$ & $0,167 \mathrm{aA}$ \\
\hline \multirow{5}{*}{ Chlorophyll index (SPAD) } & $\mathrm{L}$ & $24,6 \mathrm{bA}$ & $25,0 \mathrm{cA}$ & $26,0 \mathrm{bA}$ \\
& $\mathrm{L}+\mathrm{S}$ & $26,0 \mathrm{bA}$ & $26,6 \mathrm{abA}$ & $26,0 \mathrm{bA}$ \\
& $\mathrm{L}+\mathrm{S} 1+\mathrm{CM}$ & $25,3 \mathrm{bA}$ & $26,0 \mathrm{abcA}$ & $25,3 \mathrm{bA}$ \\
& $\mathrm{L}+\mathrm{S} 2+\mathrm{CM}$ & $25,3 \mathrm{bA}$ & $25,3 \mathrm{bcA}$ & $26,3 \mathrm{bA}$ \\
& $\mathrm{L}+\mathrm{C}$ & $28,6 \mathrm{aB}$ & $27,3 \mathrm{aB}$ & $30,3 \mathrm{aA}$ \\
\hline
\end{tabular}

Means followed by the same lowercase letter in the column (substrates) and upper case in the line (water retention capacity) do not differ by the Tukey test at $5 \%$ of probability. $((\mathrm{L})=$ latosol; $(\mathrm{L}+\mathrm{S})=$ latosol + sand in a ratio of $1: 1 ;(\mathrm{L}+\mathrm{S} 1=\mathrm{CM})=$ latosol + sand + chicken manure in a ratio of 1:1:0.5; $(\mathrm{L}+\mathrm{S} 2+\mathrm{CM})=$ latosol + sand + chicken manure in the ratio of 1:2:0.5; $(\mathrm{L}+\mathrm{C})=$ latosol + commercial substrate in a ratio of $1: 1$.

There was no significant correlation between chlorophyll content and WRC, with the exception of latosol + commercial substrate, which provided higher means when seedlings were cultivated at $100 \%$ of WRC. Root dry mass decreased with water availability. Lower values were observed in plants cultivated in latosol but no significant difference was observed in the other substrates (Table 4). Dickson quality index was higher for substrates containing sand, chicken manure, or commercial substrate, as well as for higher water availability.

Table 4. Root dry mass and Dickson quality index for seedlings of Alibertia edulis according to different substrates and water retention capacities.

Tabela 4. Massa seca de raiz e índice de qualidade de Dickson de plântulas de Alibertia edulis em função de diferentes substratos e capacidades de retenção de água.

\begin{tabular}{|c|c|c|c|c|c|}
\hline \multirow{2}{*}{ Evaluated parameters } & \multicolumn{5}{|c|}{ Water retention capacity (\%) } \\
\hline & & & 75 & & 100 \\
\hline Root dry mass (g) & & & $0,072 \mathrm{~b}$ & & $0,087 \mathrm{a}$ \\
\hline \multirow[t]{3}{*}{ Dickson quality index } & & & $0,039 \mathrm{~b}$ & & $0,052 \mathrm{a}$ \\
\hline & \multicolumn{5}{|c|}{ Substrate } \\
\hline & $\mathrm{L}$ & $\mathrm{L}+\mathrm{S}$ & $\mathrm{L}+\mathrm{S} 1+\mathrm{CM}$ & $\mathrm{L}+\mathrm{S} 2+\mathrm{CM}$ & $\mathrm{L}+\mathrm{C}$ \\
\hline Root dry mass (g) & $0,040 \mathrm{~b}$ & $0,083 \mathrm{a}$ & $0,075 \mathrm{a}$ & $0,071 \mathrm{a}$ & $0,078 \mathrm{a}$ \\
\hline Dickson quality index & $0,025 \mathrm{~b}$ & $0,049 \mathrm{a}$ & $0,039 \mathrm{a}$ & $0,045 \mathrm{a}$ & $0,047 \mathrm{a}$ \\
\hline
\end{tabular}

Means followed by the same lowercase letter in the column (substrates) do not differ by the Tukey test at $5 \%$ of probability. (L) = latosol; $(\mathrm{L}+\mathrm{S})=$ latosol + sand in a ratio of 1:1; $(\mathrm{L}+\mathrm{S} 1=\mathrm{CM})=$ latosol + sand + chicken manure in a ratio of 1:1:0.5; $(\mathrm{L}+\mathrm{S} 2+\mathrm{CM})=$ latosol + sand + chicken manure in the ratio of 1:2:0.5; $(\mathrm{L}+\mathrm{C})=$ latosol + commercial substrate in a ratio of 1:1.

\section{DISCUSSION}

The percentage of seedling emergence was higher (44\%) than that observed by Santos et al. (2014) for the same species used in this study. However, it was lower compared to studies performed under laboratory conditions, such as those by Nunes et al. (2014) and Bento et al. (2016). The differences in germination performance can be attributed to the water level of the seed at the time of planting, as suggested by Bento et al. (2016).

The lowest percentages of emergence were observed at $25 \%$ and $50 \%$ of WRC, indicating that WRC higher than $50 \%$ should be used for the studied substrates. This behavior was also observed for other Cerrado species, such as Hancornia speciosa (GORDIN et al., 2016), which presented growing values of emergence as the WRC increased over 50\%. From this point on, the percentage of emergence increases as the substrate moisture increases, possibly due to the higher water requirement of the species in the initial stages of germination, since water is one of the most important factors in the germination process.

However, this was not the observed for the substrate latosol. The percentage of emergence decreased at $100 \%$ of WRC, possibly due to the interference of aeration in this substrate. Dystroferric Red Latosol is characterized as very clayey and has lower percentage of macropores. A sufficient supply of water is essential 
for the germination process, as water absorption initiates the breakdown, movement, and assimilation of nutrient reserves (MARCOS FILHO, 2015).

The results of emergence rate are consistent with those from Scalon and Jeromini (2013), who evaluated the emergence velocity of Eugenia pyriformis and found the highest values for substrate latosol + Bioplant ${ }^{\circledR}$ at $75 \%$ of WRC. The presence of organic matter and sand in the substrates may have improved emergence velocity, since they both might enable greater gas exchange and better drainage, as well as reduce the physical barrier to initial development of the seedling (SILVA et al., 2016).

The highest average growth of the shoot after 175 days was measured at $4.6 \mathrm{~cm}$, underscoring the slow growth of this species (OLIVEIRA et al., 2015). This slow growth is very unsettling when considering the significant degradation of the Cerrado, the possibility of using this species in the recovery of this environment, and the continued maintenance of this germplasm. Thus, this emphasizes the need to preserve these areas and use them sustainably.

Gordin et al. (2016) noted in their review that a reduction in leaf expansion and size may be observed under water deficit, as this process is governed by cellular turgor. In turn, this situation can lead to a decrease in the photosynthetic activity and, consequently, lesser dry mass and plant growth. The highest values for root growth of the seedling may occur due to greater synthesis of abscisic acid in the root tissue cells, triggering growth of these cells and, consequently, greater root growth (TAIZ; ZEIGER, 2013). This response deepens the root system and increases soil exploration, making it easier for the plant to obtain water and nutrients that it needs.

The chlorophyll content was higher in the latosol + commercial substrate. This substrate is composed of organic matter, which serves as a nitrogen source for the plants. The magnesium content of this substrate is also very high. Thus, these nutrients are essential for the production of chlorophyll molecules (TAIZ; ZEIGER, 2013). The reduction of chlorophyll content in cases of lower water availability for this substrate suggests that the availability of minerals and organic matter depends on a certain level of substrate hydration. Therefore, decreased water availability may reduce chlorophyll a, chlorophyll b, and total chlorophyll levels. However, these characteristics were not evaluated in this study. Total chlorophyll content is directly correlated to the SPAD index, which also decreases in other species subjected to a water deficit (SILVA et al., 2014). Silva et al. (2014) attribute this reduction to possible damage to the photosynthetic system. Furthermore, reduction in chlorophyll $\mathrm{b}$ may lead to photo-inhibition and reduction of the photosynthetic efficiency.

Although roots tend to be longer as water availability is reduced, they are also thinner, thereby resulting in lower overall mass accumulation. This situation hinders survival of these plants in the dry season in their natural environment. Indeed, the greater the development of the root system, the greater the chance of survival in the natural environment, since the seedlings exhibit better water absorption and soil support (LIMA et al., 2008). Dickson quality index is considered an important parameter for evaluating seedling quality and has been applied to several native Cerrado species (SCALON; JEROMINI, 2013, DRESCH et al., 2016, GORDIN et al., 2016). The positive results for plant growth and development observed in substrates composed of sand and chicken manure can be attributed to aeration, higher moisture retention, chemical composition, and temperature maintenance, as previously reported for Campomanesia adamantium (DRESCH et al., 2016). However, latosol + commercial substrate may have supplied a greater amount of nutrients than the other substrates as it has more organic matter, calcium, and magnesium (Table 1). This characteristic facilitates greater development of the shoot part and root system, as well as increased mass accumulation, as observed for $H$. speciosa (GORDIN et al., 2016) Eugenia dysenterica (SILVA et al., 2011), and E. uniflora (ANTUNES et al., 2012).

The results of this study indicate that even though A. edulis is adapted to regions subjected to water deficit, its growth characteristics respond favorably when submitted to greater water availability. Similar results were also found for C. adamantium (DRESCH et al., 2016) and Guazuma ulmifolia (SCALON et al., 2011) species that naturally grow in environments similar to the Cerrado. When submitted to water levels greater than $50 \%$ of WRC, their seedlings developed more effectively.

The quality of seedlings of A. edulis was lower only in pure latosol cultivation and did not vary significantly among the other substrates evaluated, based on the other characteristics evaluated mainly the chlorophyll index and leaf area, which are characteristics that are not computed to calculate the quality of the seedlings (DQI). Despite that, we can recommend the use of latosol + commercial substrate and WRC of $100 \%$ for the production of seedlings of A. edulis. 


\section{CONCLUSION}

- Latosol + commercial substrate at $100 \%$ of WRC provides the best conditions for the emergence of the seedling, initial growth and formation of seedlings of A. edulis.

- Sowing in the substrate of Dystroferric Red Latosol isolated at $25 \%$ of WRC should not be used for the formation of seedlings of A. edulis.

\section{REFERENCES}

ANTUNES, L. E. C.; PICOLOTTO, L.; VIGNOLO, G. K.; GONÇALVES, M. A. Influência do substrato, tamanho de sementes e maturação de frutos na formação de mudas de pitangueira. Revista Brasileira de Fruticultura, Jaboticabal, v.34, n.4, p.1216 - 1223, 2012.

AQUINO DFDE S.; TIRLONI C.A.S.; MENEGATTI, S.E.L.T.; CARDOSO, C.A.L.; VIEIRA, S. C. H.; VIEIRA, M. C.; SIMONET, A. M.; MACÍAS, F. A.; GASPAROTO, A. Alibertia edulis (LC Rich.) AC Rich-A potent diuretic arising from Brazilian indigenous species. Journal of Ethnopharmacology, Pretoria, v.19, n. 6, p. $193-200,2017$.

BENTO, L.F.; DRESCH, D.M.; SCALON, S.P.Q.; MASETTO, T.E. Storage of Alibertia edulis seeds: Influence of water content and storage conditions. African Journal of Agricultural Research, Lagos, v.11, n.18, p.1646 $1655,2016$.

BRASIL. Ministério da Agricultura, Pecuária e Abastecimento. Instruções para análise de sementes de espécies florestais. Brasília: MAPA/ACS, 2013. 97p.

DICKSON, A.; LEAF, A.L.; HOSNER, J.F. Quality appraisal of white spruce and white pine seedlings stock in nurseries. Forest Chronicle, Ottawa, v 36, p 10 - 13, 1960.

DRESCH, D.M.; SCALON, S.P.Q.; MUSSURY, R.M.; KODAMA, F.M. Initial growth of Campomanesia adamantium (Cambess.) O. Berg. seedlings on substrates with different compositions and water retention capacities. Bioscience Journal, Uberlândia, v.32, n.1, p.1 - 10, 2016.

DUTRA, T.R.; MASSAD, M.D.; SARMENTO, M.F.Q.; OLIVEIRA, J.C. Emergência e crescimento inicial da canafístula em diferentes substratos e métodos de superação de dormência. Revista Caatinga, Mossoró, v.25, n.2, p. $65-71,2012$.

FIETZ, C.R.; FISCH, G.F. O clima da região de Dourados, MS. Dourados: Embrapa Agropecuária Oeste, 2006. 32p.

GORDIN, C.R.B.; MARQUES, R.F.; SCALON, S.P.Q. Emergence and initial growth of Hancornia speciosa (Gomes) seedlings with different substrates and water availability. Revista de Ciências Agrárias, Belém, v.59, n.4, p.352 - 361, 2016.

LIMA, J.D.; SILVA, B.M.S.; MORAES, W.S.; DANTAS, V.A.V.; ALMEIDA, C.C. Efeitos da luminosidade no crescimento de mudas de Caesalpinia ferrea Mart. ex Tul. (Leguminosae, Caesalpinoideae). Acta Amazônica, Manaus, v.38, n.1, p.5 - 10, 2008.

MAGUIRE, J.B. Speed of germination-aid in selection and evaluation for seedling emergence vigor. Crop Science, Madison, v.2, n.2, p.176 - 177, 1962.

MARCOS FILHO J. Fisiologia de sementes de plantas cultivadas. Piracicaba: Fealq, 2015. 495p.

NUNES, D.P.; SCALON, S.P.Q.; BONAMIGO, T.; MUSSURY, R.M. Germinação de sementes de marmelo: temperatura, luz e salinidade $=$ Germination of the quince. Bioscience Journal, Uberlândia, v.30, n.6, p.1737 $1745,2014$.

OLIVEIRA, V.C.; JOLY, C.A. Flooding tolerance of Calophyllum brasilienseCamb. (Clusiaceae): morphological, physiological and growth responses. Trees, Berlin, v.24, n.1, p.185 - 193, 2010.

OLIVEIRA, M.C.; PASSOS, F.B.; RIBEIRO, J.F.; AQUINO, F.G.; OLIVEIRA, F.F.; SOUSA, S.R. Crescimento de espécies nativas em um plantio de recuperação de Cerrado sentido restrito no Distrito Federal, Brasil. Revista Brasileira de Biociências, Porto Alegre, v.13, n.1, p.25-32, 2015. 
RIBEIRO, J.F.; WALTER, B.M. T. As principais fitofisionomias do bioma Cerrado. In: SANO, S. M.; ALMEIDA, S. P.; RIBEIRO, J. F. Cerrado: ecologia e flora. Brasília: (Eds) 2008. Embrapa Informação e Tecnologia. p.151-212.

SANTOS, H.G.; JACOMINE, P.K.T.; ANJOS, L.H.C.; OLIVEIRA, V.A.; LUMBRERAS, J.F.; COELHO, M.R.; ALMEIDA, J.A.; CUNHA, T.J.F.; OLIVEIRA, J.B. Sistema brasileiro de classificação de solos. 3.ed. rev. e ampl. Brasília: Embrapa, 2013. 353p.

SANTOS, C.C.; VIEIRA, M.C.; EDTI, P.J.; ZÁRATE, N.A.; CARNEVALI, T.O.; ARAN, H.D.V. R. Avaliação de substratos na emergência e crescimento inicial de marmelo do cerrado (Alibertia edulisRich) em bandejas. Cadernos de Agroecologia, v.9, n.4, p.01, 2014.

SCALON, S.P.Q.; MUSSURY, R.M.; EUZÉBIO, V.L.M.; KODAMA, F.M.; KISSMANN, C. Estresse hídrico no metabolismo e crescimento inicial de mudas de mutambo (Guazuma ulmifolia Lam.). Ciência Florestal, Santa Maria, v. 21, n.4, p.657 - 664, 2011.

SCALON, S.P.Q.; JEROMINI, T.S. Substratos e níveis de água no potencial germinativo de sementes de uvaia. Revista Árvore, Viçosa, v.37, n.1, p.49 - 58, 2013.

SCALON, S.P.Q.; JEROMINI, T.S.; MUSSURY, R.M.; DRESCH, D.M. Photosynthetic metabolism and quality of Eugenia pyriformis Cambess. seedlings on substrate function and water levels. Anais da Academia Brasileira de Ciências, Rio de Janeiro, v. 86, n.4, p.2040 - 20148, 2014.

SILVA, E.A.; OLIVEIRA, A.C.; MENDONÇA, V.; SOARES, F.M. Substratos na produção de mudas de mangabeira em tubetes. Pesquisa Agropecuária Tropical, Goiânia, v.41, n.2, p.279 - 285, 2011.

SILVA, M.A.; SANTOS, C.M.; VITORINO, H.S.; RHEIN, A.F.L. Pigmentos fotossintéticos e índice SPAD como descritores de intensidade do estresse por deficiência hídrica em cana-de-açúcar. Bioscience Journal, Uberlândia, v.30, n.1, p.173 - 181, 2014.

SILVA, G.Z.S.; VIEIRA, V.A.C.; BONETTI, J.E.B.B.; MELO, L.F.; MARTINS, C.C. Temperature and substrate on seed germination. Revista Brasileira de Engenharia Agrícola e Ambiental, Campina Grande, v.20, n.11, p.1031 - 1035, 2016.

TAIZ, L.; ZEIGER, E. Fisiologia Vegetal. 5. ed. Porto Alegre: Artmed, 2013. 918p. 
FLORESTA, Curitiba, PR, v. 49, n. 1, p. 089-098, jan/mar. 2019 Jeromini. T. S. et.al. ISSN eletrônico 1982-4688 DOI: 10.5380/rf.v49i1.57122 